\title{
Proofing Tools in Microsoft Office Word 2019: The Application in Indonesian Language
}

\author{
Arief Fiddienika \\ arieffiddienika@unm.ac.id \\ Universitas Negeri Makassar
}

\begin{abstract}
Microsoft Office Word 2019 has grammar correction in various languages, one of which is Indonesian. This paper aims to explore the features of the spelling and inspection tools of Microsoft Office Word 2019. This verification tool was tested with Indonesian linguistic units, compound words, affixes, and particles. In addition, the testing was also carried out on Indonesian punctuation. From this research it was found that the Microsoft Office Word 2019 system proofing tools only works best when errors occur in words and reduplication. This tool cannot detect errors in using punctuation, errors at the syntactical level and at the semantic level. The realm of sentences and meanings did not pass this test.
\end{abstract}

Keywords: Microsoft Office Word, proofing tools, spelling

\section{Introduction}

Writing is important in writing papers, books, magazines, and others, not only for individuals but also government offices, companies, including editors. An editor is a person who edits manuscripts or essays that will be published in magazines, newspapers, books, etc. (Sugihastuti, 2014). It is thus reasonable that writing tools have developed rapidly, from stone, slate, typewriter to computer. In digitalization era today, the use computer as a writing tool is growing rapidly. A lot of software programs have been introduced one of which is Microsoft Office.

Microsoft Office for Windows started in 1990 as a package of Microsoft Windows 3.0 operating system, Microsoft Word for Windows 1.1, Microsoft Excel for Windows 2.0, and Microsoft PowerPoint for Windows 2.0. In 1995 Microsoft relaunched this office application with the 1995 version along with its Windows 95 Operating System. In this operating system Microsoft completely overhauled Windows versions 3.1 and Windows 3.11 for Workgroups. After that came the innovations from Microsoft Office, from Microsoft Office 2000, Microsoft Office XP, Microsoft Office 2003, Microsoft Office 2007, Microsoft Office 2010, Microsoft Office 2013, to the latest is Microsoft Office 2019. The rapidly growing digital era with the use of smart phones make this company create Mobile version, either from Microsoft Office Word to Microsoft Office Lens.

One of the flagship software from Microsoft Office 2019 package is Microsoft Office Word 2019. Since version 2003, this device has started to apply spelling and grammar tools up to 50 languages. However, many users of this software ignore the spelling tool features. Therefore, red waves are often found beneath the text which is a warning that typed words are not found in the dictionary. This makes the scene screen to be disturbed. Consider the following example. 


\subsection{Latar Belakang \\ Dalam konteks kompetisi global saat ini, sektor pariwisata harus mampu bersaing baik dengan pesaing lokal maupun global. Banyak negara sejak beberapa tahun terakhir menganggap pariwisata dengan serius dan menjadikan pariwisata sebagai sektor unggulan di dalam memperoleh devisa, menciptakan lapangan kerja, maupun pengentasan kemiskinan (Pinata dan Diarta, 2009). Pariwisata menjadi sorotan paling utama, terutama bagi negara berkembang seperti Indonesia.}

Figure 1. Example of display software on the screen

In Figure 1 above it is very visible that people usually write in Microsoft Office Word software. The cause of the red wave is the mismatch between the language on the keyboard and the typed language. This unattractive scene sometimes makes writers less careful in editing their writings and finally they prefer to print it first before editing it.

Research on the detection of punctuation errors has been carried out under the title "Tool of Assisting Punctuation Detection in Scientific Writing"(Anggraini, Zinni, \& Rochimah 2016). This research is intended to create a tool for detecting punctuation errors in scientific papers with .doc or .docx files. Tests on the developed instrument were tested on punctuation in Indonesian by using the Boyer-Moore algorithm and it was concluded that the system could detect errors in the use of spaces between words and punctuation errors. However, the system several times also detected punctuation errors even though the punctuation was not wrong. The other research on language errors was done by Umboh, Sentinuwo and Sambul (2017) by using an error detection application in a thesis. The error detection application that was approved in a thesis document script was very helpful for finding errors in approving. However, there was no spelling correction feature after error detection. Taufik, Aishia and Jumadi (2017) also examined the implementation of Fuzzy Search which was used for detection of foreign words in Microsoft Word. However, this study only detected foreign words in Indonesian texts and did not detect Indonesian grammatical errors. Miftahuddin, Pardede and Dewi (2018) applied the lemmatization algorithm to Indonesian documents. In that study, text preprocessing and lemmatization were used to determine incorrect spelling errors. So, this research only detected words that were in accordance with KBBI and could not provide suggestions if a writing error occurs.

From the description above, the purpose of writing this paper is to explore the spelling and grammar tool features of Microsoft Office Word 2019 software from the way it was installed into things that have not been detected in this software. The testing of this tool was carried out with Indonesian linguistic units, both in terms of words, combination of words, punctuation, sentences, and meanings. This test was conducted to obtain empirical data about the feasibility of using spelling and grammar tools in Indonesian.

\section{Theory and Method}

In order to be able to conduct this study the Indonesian language was first configured in the computer where the Microsoft Office Word 2019 was being installed and used (Lambert, 2019; Lambert \& Frye, 2015). The data for this study were taken from samples in the form of words, phrases, and Indonesian sentences, in terms of morphological, syntactic, and semantic elements written in the Microsoft Office Word 2019. Method used in collecting the data was the introspection method, which fully utilizes the role of researchers as speakers of languages (Mahsun, 2012). 
The data analysis used was the comparative method of comparative linking techniques and the distribution method with substitution techniques (Sudaryanto, 2015). This was intended to test the suitability of the Indonesian grammar with the Indonesian grammatical system that could be detected by Microsoft Office Word 2019. At the stage of presenting the results of data analysis, an informal method was used. In order to get a better understanding of the results from this study, the method of informal presentation was used by using the formulation of ordinary words although it used technical terminology.

\section{Findings and Discussion}

In this discussion will be discussed the extent to which the ability of this tool can function in identifying the Indonesian language from the smallest order in the form of letters to syntactic order.

When in word-by-word correction, this tool is helpful when writing is false. Consider the following example.

\section{Perangkat lunak ini mendteksi berbagai macam bahasa.}

Figure 2. Example display of the wrong word on the screen

In the example above there is a word in italics with a wave line underneath. This example proves that this spell checker is working properly. When that happens, just right click on the mouse and select the appropriate word.

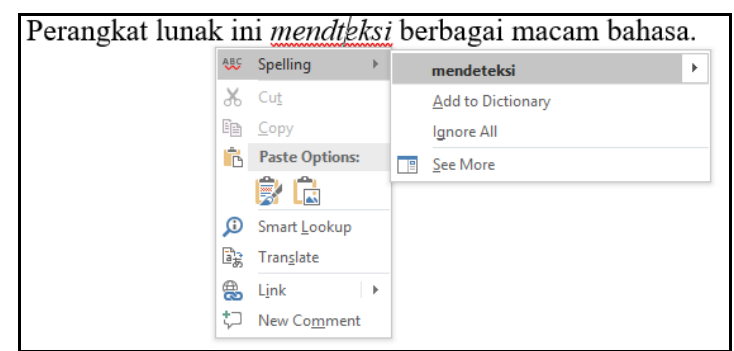

Figure 3. How to correct the wrong word

The problem that often happens is when typing errors in a word makes another meaningful word. Consider the following example.

Perangkat lunak ini mendeteksi berbagai macan bahasa.

Figure 4 . The sentence with wrong word but has other meaning

In this example, the word macan should be a macam. However, this detector does not give a red mark under the word because in Indonesian there is the word macan 'tiger'

When writing typically occurs repetition of words due to the author is less focused with the words that are typed. Look at the example below.

Provinsi Yogyakarta merupakan salah satu provinsi di Indoensia yang memiliki
aset daya tarik tarik baik alam maupun budaya.

Figure 5. Sample of the re-word

There is a repetition of the word in the example above, such the word tarik. The proofing tools feature also works well by providing a red line on the repeated word. The 
word can be removed manually by using the delete or backspace key. In addition, the word can be removed by pressing the right button on the mouse and the cursor is directed to the word with red lines. Look at the following example.



Figure 6. How to correct the re-word

The use of the word above can be well resolved with the proofing tool. In the repeated form, this spellchecking tool also runs smoothly when the author does not insert a hyphen between the words.

The reduplication process is available in many languages, including in Indonesian. Reduplication is a morphemically process that repeats the basic or partial form of the basic form (Verhaar, 2008). There are several types of reduplication in Indonesian one of them is dwilingga. Consider the following example.

\section{Meja meja itu harus dirapikan sebelum acara dimulai.}

Figure 7. The other type of the wrong re-word

In the example it appears that the repeat word will be detected properly with this checker if the writer is typing wrongly. However, in this case, the examiner cannot correct automatically by clicking the right mouse button and the word meja-meja appears. The solution that should be applied by the author is to manually insert a hyphen between the rewords.

\section{Meja-meja itu harus dirapikan sebelum acara dimulai.}

Figure 8 . The correct format of the re-word

In the example, the proofing tool does not provide a red line because the author has added hyphen between re-word.

Switching from nouns, checking is applied toward verbs. In terms of form, Indonesian verbs are divided into two forms, they are free basic verbs and bounded base verbs. The bound form, yet can be incorporated into any word class and has no independent meaning (Alwi, 2000). On this occasion will be discussed on the basic form of 'selenggara'. Look at the following example.

Acara ini tidak akan $\{$ ter- $\}$ selenggara jika kamu tidak datang.

Figure 9. Sample that the tool cannot detect the false verb

When the base verb is bound to be typed, there should be a red line under the word because the bounded base verb cannot be inserted into any word class in the sentence. This proves that the basic form verb that should not be able to be put into any word class, its error is not detected by the proofing tool.

Among the morphemically processes, the most important is affix (Alwi, 2000; Chaer, 2006, 2007; Muslich, 2010; Verhaar, 2008) mentions four kinds of affixes in Indonesian, 
namely prefixes, suffixes, confix and unproductive one is infix. In this case we will discuss the derived form of some compound verbs. Look at the following example.

\begin{tabular}{|l|l|}
\hline \multicolumn{2}{|c|}{ anak tiri } \\
\hline menganaktirikan & menganak tirikan \\
\hline penganaktirian & penganak tirian \\
\hline \multicolumn{2}{|c|}{ tanggung jawab } \\
\hline bertanggungjawab & bertanggung jawab \\
\hline mempertanggungjawabkan & mempertanggung jawabkan \\
\hline menanggungjawab & menanggung jawab \\
\hline penanggungjawab & penanggung jawab \\
\hline pertanggungjawaban & pertanggung jawaban \\
\hline & sebar luas \\
\hline menyebarluaskan & menyebar luaskan \\
\hline penyebarluasan & penyebar luasan \\
\hline tersebarluas & tersebar luas \\
\hline
\end{tabular}

Figure 10. Some examples of the affixation of the combinations word

The table above contains three compound verbs, namely anak tiri, tanggung jawab and sebar luas. All three compound verbs have different affixes. By a rule, if the verb is flanked by a prefix and suffix, then the verb is merged. However, if there is only one affix attached, be it a prefix or suffix, then the writing will be separated (Tim Pengembang Pedoman Bahasa Indonesia, 2016). In the table above, there are only three derivative forms that are given a red line underneath, they are menganak tirikan, penganak tirian and penanggungjawab. In addition to the above three derivative forms, writing errors are not detected by the spell checker tool. For example, in the word menyebar luaskan*. When this word is separated, it will bring up another word that is menyebar and luaskan. It is for this reason that this spell checker cannot detect any writing errors in this derivative.

Preposition is a particle which in VO language is usually located in front of nouns and relates it to other words in exocentric bond (Kridalaksana, 2001). In Indonesian language there are several prepositions, one of which is ' $d i$ '. The writing of the preposition in the Indonesian language is split with the following word. The Proofing tool in Microsoft Office Word 2019 can also detect the preposition in the Indonesian language well. Look at the following example.

$$
\begin{aligned}
& \text { Ibu sedang menggoreng telur didapur. * } \\
& \text { Ibu sedang menggoreng telur di dapur. }
\end{aligned}
$$

Figure 11. Incorrect and correct preposition typing

In this example, this inspection tool can detect the prepositional error in the first sentence, that is, the word 'didapur'. When written correctly, this software does not put a red mark under the preposition 'di dapur'. From this explanation it is clear that the proofing tools system can detect prepositional writing errors.

The next test is how Indonesian punctuation is detected by the proofing tools system. Indonesian spelling has fifteen punctuation marks, which are periods (.), Commas (,), semicolons (;), colons (:), dashes (-), dashes (-), question marks (?), exclamation point (!), ellipses (...), quotation marks ("..."), single quotes ('...'), parentheses $((\ldots))$, square brackets ([ ...]), slashes (/), and abbreviations or apostrophes (') (Tim Pengembang Pedoman Bahasa Indonesia, 2016). 


\begin{tabular}{|c|c|c|c|}
\hline No. & WRONG SENTENCES & CORRECT SENTENCES & PUNCTUATION \\
\hline 1. & $\begin{array}{l}\text { Muhammad sedang. } \\
\text { Memakan nasi. (1a) }\end{array}$ & $\begin{array}{l}\text { Muhammad sedang } \\
\text { memakan nasi. (1b) }\end{array}$ & Point \\
\hline 2. & $\begin{array}{l}\text { Mobil gawai atau internet } \\
\text { bukan barang mewah } \\
\text { lagi. (2a) }\end{array}$ & $\begin{array}{l}\text { Mobil, gawai, atau internet } \\
\text { bukan barang mewah lagi. } \\
\text { (2b) }\end{array}$ & \multirow[t]{2}{*}{ coma } \\
\hline 3. & $\begin{array}{l}\text { Kalau diundang saya } \\
\text { akan datang. (3a) }\end{array}$ & $\begin{array}{l}\text { Kalau diundang, saya akan } \\
\text { datang. }(3 \mathrm{~b})\end{array}$ & \\
\hline 4. & $\begin{array}{l}\text { Hari sudah malam ayah } \\
\text { belum juga pulang. (4a) }\end{array}$ & $\begin{array}{l}\text { Hari sudah malam; ayah } \\
\text { belum juga pulang. (4b) }\end{array}$ & Semicolon \\
\hline 5. & $\begin{array}{l}\text { Mereka memerlukan } \\
\text { perabot masak panci, } \\
\text { wajan, dan spatula. (5a) }\end{array}$ & $\begin{array}{l}\text { Mereka memerlukan perabot } \\
\text { masak: panci, wajan, dan } \\
\text { spatula. (5b) }\end{array}$ & Colon \\
\hline 6. & $\begin{array}{l}\text { Anak anak, bapak bapak } \\
\text { kupu kupu (6a) }\end{array}$ & $\begin{array}{l}\text { Anak-anak, bapak-bapak, } \\
\text { kupu-kupu (6b) }\end{array}$ & \multirow{3}{*}{ Hyphen } \\
\hline 7. & $\begin{array}{l}\text { Tahun } 50 \text { an, } 50 \text { an, ber } \\
\text { KTP, berKTP (7a) }\end{array}$ & Tahun 50-an, ber-KTP (7b) & \\
\hline 8. & Dibackup diinstall (8a) & di-backup di-install (8b) & \\
\hline 9. & $\begin{array}{l}\text { Apa tujuan penelitianmu } \\
\text { (9a) }\end{array}$ & $\begin{array}{l}\text { Apa tujuan penelitianmu? } \\
(9 b)\end{array}$ & Question mark \\
\hline 10. & $\begin{array}{l}\text { Bayar dulu baru makan } \\
\text { Merdeka (10a) }\end{array}$ & $\begin{array}{l}\text { Bayar dulu baru makan! } \\
\text { Merdeka! (10b) }\end{array}$ & Exclamation mark \\
\hline 11. & $\begin{array}{l}\text { Maaf, begitu kata Budi. } \\
\text { (11a) }\end{array}$ & $\begin{array}{l}\text { "Maaf", begitu kata Budi. } \\
\text { (11b) }\end{array}$ & Quotation mark \\
\hline 12. & $\begin{array}{l}\text { "Kau dengar bunyi } \\
\text { kring-kring tadi?" (12a) }\end{array}$ & $\begin{array}{l}\text { "Kau dengar bunyi 'kring- } \\
\text { kring" tadi?" (12b) }\end{array}$ & Single quotes \\
\hline 13. & $\begin{array}{l}\text { Tono belum memiliki } \\
\text { KTP kartu tanda } \\
\text { penduduk (13a) }\end{array}$ & $\begin{array}{l}\text { Tono belum memiliki KTP } \\
\text { (kartu tanda penduduk) } \\
\text { (13b) }\end{array}$ & Brackets \\
\hline 14. & $\begin{array}{l}\text { Harganya Rp. } 2500,00 \\
\text { buah (14a) }\end{array}$ & $\begin{array}{l}\text { Harganya Rp. } 2500,00 / \text { buah } \\
(14 \mathrm{~b})\end{array}$ & Slash \\
\hline 15. & $\begin{array}{l}\text { Dia kan bahagia } \\
\text { bersamamu (15a) }\end{array}$ & $\begin{array}{l}\text { Dia "kan bahagia } \\
\text { bersamamu (15b) }\end{array}$ & Apostrophe \\
\hline
\end{tabular}

Figure 11. Punctuation testing

In the first data, testing is done by giving a number of points in (1a). The system will detect when there is a point, then the beginning of the word after that will become capital. This is detected by the autocorrect feature, which captures first letter of sentences. In addition to this, the system does not detect errors using the dot that occurs in the sentence.

In data 2 to data 5, no errors were detected at all. Data 2 and 3 are the use of commas, data 4 is the use of semicolons, and data 5 is colon. In the use of commas, the system cannot detect the elements specified using commas (2a) and commas that are used to separate clauses that precede the parent sentence (3a). Two of the 13 existing comma functions, the system cannot detect any errors at all. Data 4 is an example of the semicolon function as a substitute for conjunctions to separate one equivalent sentence from another equivalent sentence in compound sentences. In (4a), the system also cannot detect errors in the use of punctuation in sentences. Data 5 is a colon which serves to end a complete statement followed by a description or explanation. However, the system also did not detect the error in (5a).

Errors that are detected by the system are hyphen in reduplication (data 6) and hyphen between numbers and letters or lowercase letters and capital (data 7). However, in data (7b) and (8b), the system cannot detect the correct writing according to Indonesian 
language guidelines with data (7b) [ber-] cannot stand apart from verbs so that the word 'ber-KTP' system detects language use errors, and at data (8b) the system still detects that the words 'install' and 'backup' are foreign words in Indonesian. Apart from the punctuation described above, the system cannot read the existing punctuation errors.

Question marks (9) are used as endings for question words, exclamation points (10) are used for statement expressions in the form of exclamations in the form of commands, quotation marks (11) are used for flanking direct passages, single quotes (12) are used for sandwiching quotes in quotes, parentheses (13) are used to surround additional information or explanations, slashes (14) are used to substitute words and, or, and each, and apostrophes (15) are used to substitute omission of words or parts of year numbers in a particular context(Tim Pengembang Pedoman Bahasa Indonesia, 2016). However, from some of the things that have been explained, the Microsoft Office Word Proofing System cannot detect Indonesian punctuation errors.

Stepping into the next test is in the syntactic domain. A sentence can be composed of a subject, a predicate, an object and an adverb. If the arrangement is scrambled, does this software also detect errors occurring from the arrangement. Look at the example below.

$$
\begin{aligned}
& \text { a. Ibu sedang menggoreng telur di dapur. } \\
& \text { b. Ibu sedang di dapur telur menggoreng.* } \\
& \text { c. Ibu telur sedang di dapur menggoreng.* } \\
& \text { d. Sedang ibu telur menggoreng dapur di.* } \\
& \text { e. Ibu sdang di telur mengoreng dapur.* } \\
& \text { f. Ib sedang di menggoreng tlur dpur.* }
\end{aligned}
$$

Figure 12. Some example of the true and the false sentences

Of the six sentences, there is one sentence that is correct in the sentence a. In the sentence $b, c$ and $d$ not a sentence with the correct order, but the proofing tool does not detect these errors. While in sentences e and $\mathrm{f}$, is not a sentence with the correct order and some spelling is wrong. In the sentences e and $\mathrm{f}$, there are some red lines provided by this proofing tool due to errors in word writing, not the wrong sentence arrangement.

The last test is at the level of meaning. Before testing, the researcher thought that proofing tools could not detect meaning errors. This is seen from the errors detected in the discussion above. In terms of meaning, researchers test the system by using the minimal pairs. The use of a minimum pair is intended to know the non-acceptance of words in the sentence being tested. By not accepting words in the sentence, the system is expected to detect errors in those sentences. In this study, a minimum pair of $/ \mathrm{n} / \mathrm{and} / \mathrm{m} /$ in the words 'macan' and 'macam'. will be used.

a. Di supermarket, dijual berbagai macam kebutuhan rumah tangga.

b. Di supermarket, dijual berbagai macan kebutuhan rumah tangga.*

c. Di supermarket, dijual macan macam kebutuhan rumah tangga.*

d. Di supermarket, dijual macam macam kebutuhan rumah tangga.*

e. Di supermarket, dijual macam-macam kebutuhan rumah tangga.

f. Di supermarket, dijual macan macan kebutuhan rumah tangga. *

Figure 13. Semantic testing using minimal pairs

From the example above it can be seen that the system cannot detect errors of meaning. In that sentence, what should be used is 'macam', but the system cannot detect the 
error that occurs if the word 'macam' is replaced by 'macan'. This shows that Microsoft Office Word 2019 proofing tools cannot detect errors at the semantic level.

\section{Conclusion}

From the above description can be concluded as follows. The proofing tool is very effective at correcting spelling errors in letters and words, but it is not effective when correcting word combinations to sentences. This happens because the proofing tool works based on the vocabulary entered in Indonesian package dictionary. Therefore, the proofing tool only works best when errors occur in the word and reduplication levels. This tool cannot detect errors in using punctuation, errors at the grammatical level of syntax and also at the semantic level. For users of this software would be better to keep thinking of grammar, while this checking tool is just as a typing tool that serves to give warning to its users when it is wrong in typing words.

\section{References}

Alwi, Hasan. 2000. Tata Bahasa Baku Bahasa Indonesia. Jakarta: Balai Pustaka.

Anggraini, Ratih Nur Esti, Mohammad Ahmaluddin Zinni, \& Siti Rochimah. 2016. Kakas bantu pendeteksi kesalahan tanda baca pada karya tulis ilmiah. JUTI: Jurnal Ilmiah Teknologi Informasi, 14(1), 117.

Chaer, Abdul. 2006. Tata Bahsa Praktis Bahasa Indonesia. Jakarta: PT Rineka Cipta.

Chaer, A. 2007. Linguistik Umum. Jakarta: PT Rineka Cipta.

Kridalaksana, Harimurti. 2001. Kamus Linguistik. Jakarta: PT Gramedia Pustaka Utama.

Lambert, Joan \& Curtis Frye. 2015. Microsoft Office 2016 Step by Step. Washington: Microsoft Press.

Mahsun. 2012. Metode Penelitian Bahasa Tahapan Strategi, Metode, dan Tekniknya. Rajawali Press: Jakarta.

Microsoft Support. (n.d.). Diambil 28 Januari 2020, dari https://support.microsoft.com/enus/search?query=how to change the keyboard language and input the language

Miftahuddin, Y., Pardede, J. \& Dewi, R. 2018. Penerapan algoritma lemmatization pada dokumen Bahasa Indonesia. MIND Journal, 3(2), 47-56.

Muslich, Masnur. 2010. Garis-Garis Besar Tata Bahasa Baku Bahasa Indonesia. Bandung: PT Refika Aditama.

Sudaryanto. 2015. Metode dan Aneka Teknik Analisis Bahasa. Yogyakarta: Sanata Dharma University Press.

Sugihastuti. 2014. Editor Bahasa. Yogyakarta: Pustaka Pelajar.

Taufik, I., Aishia, I. D. \& Jumadi. 2017. Implementasi fuzzy search untuk pendeteksi kata asing pada dokumen Microsoft Word. Jurnal Teknik Informatika.

Tim Pengembang Pedoman Bahasa Indonesia. 2016. Pedoman Umum Ejaan Bahasa Indonesia. Jakarta: Badan Pengembangan dan Pembinaan Bahasa Kementerian Pendidikan dan Kebudayaan. 
Umboh, W. W. A., Sentinuwo, S. R. \& Sambul, A. M. 2017. Rancang Bangun Aplikasi Deteksi Kesalahan Penulisan Naskah Dokumen Skripsi. E-Journal Teknik Informatika, 11(1).

Verhaar, J. W. M. 2008. Asas-Asas Linguistik Umum. Yogyakarta: Gadjah Mada University Press. 